\title{
Life Cycle Assessment of Biomass Production from Lignocellulosic Perennial Grasses under Changing Soil Nitrogen and Water Content in the Mediterranean Area
}

\author{
Danilo Scordia * (D), Giuseppina Marina D’Agosta, Mariadaniela Mantineo, Giorgio Testa and \\ Salvatore Luciano Cosentino \\ Dipartimento di Agricoltura, Alimentazione e Ambiente (Di3A), University of Catania, via Valdisavoia 5, \\ 95123 Catania, Italy; giuseppinamarina.dagosta@istruzione.it (G.M.D.); d.mantineo@icloud.com (M.M.); \\ gtesta@unict.it (G.T.); sl.cosentino@unict.it (S.L.C.) \\ * Correspondence: dscordia@unict.it; Tel.: +39-095-478-3459
}

check for updates

Citation: Scordia, D.; D'Agosta, G.M.; Mantineo, M.; Testa, G.; Cosentino, S.L. Life Cycle Assessment of Biomass Production from Lignocellulosic Perennial Grasses under Changing Soil Nitrogen and Water Content in the Mediterranean Area. Agronomy 2021, 11, 988. https://doi.org/10.3390/ agronomy11050988

Academic Editor: Susanne Barth

Received: 15 March 2021

Accepted: 13 May 2021

Published: 16 May 2021

Publisher's Note: MDPI stays neutral with regard to jurisdictional claims in published maps and institutional affiliations.

Copyright: (C) 2021 by the authors. Licensee MDPI, Basel, Switzerland. This article is an open access article distributed under the terms and conditions of the Creative Commons Attribution (CC BY) license (https:/ / creativecommons.org/licenses/by/ $4.0 /)$.

\begin{abstract}
Low iLUC risk feedstocks, such as lignocellulosic no-food crops, have been indicated as sustainable crops for the transition to a bio-based economy. Given the high output to input ratio and the environmental benefits that can be obtained from renewable heat production replacing fossil fuels, the present study addressed the biomass yield, $\mathrm{CO}_{2}$-sequestration, and life cycle assessment of giant reed (Arundo donax L.) and miscanthus (Miscanthus $\times$ giganteus Greef et Deuter) growing under different soil water availability and nitrogen fertilization for three consecutive growing seasons in a semiarid Mediterranean environment. Giant reed outperformed miscanthus, showed a higher $\mathrm{CO}_{2}$-sequestration and a lower overall environmental impact. In case of both crops, the irrigation effect was significant, while the one of nitrogen fertilization was not apparent. While giant reed responded positively to reduced irrigation, compared to its highest level, as the plantation became older, miscanthus needed high water volume to get most out its potential yield. Nonetheless, the growing season had also a significant effect on both crops, mainly when low yields were achieved following the establishment year. Unlike the environmental benefits in the impact categories "nonrenewable energy use" and "global warming potential", environmental burdens concerning ozone depletion, acidification, and eutrophication were observed, indicating that further improvements of the evaluation of impact assessment associated with bioenergy production might be necessary.
\end{abstract}

Keywords: miscanthus; giant reed; $\mathrm{LCA}$; $\mathrm{CO}_{2}$-sequestration; environmental impact

\section{Introduction}

Lignocellulosic biomass is the most abundant raw material on earth and bioenergy from lignocellulosic crops can address indirect land use changes (iLUC) emissions and avoid conflict with food markets. In the European Union, high iLUC risk feedstock (first generation crops) has been judged to be unsustainable; nowadays, emphasis is given to bioenergy and biofuels from low iLUC risk feedstock, either by promoting a biomass productivity increase per unit of land used or by growing low input requiring lignocellulosic crops on unused, abandoned, idle lands [1,2].

In the last 40 years, perennial energy grasses have been deeply investigated under countless environmental conditions and agronomic practices [3]. The wish list for a sustainable transition from a fossil to a biobased economy includes feedstock that has high and stable yield and composition, needs low agrochemical inputs, has a low water requirement and a low moisture content at harvest [4]. Whereas perennial energy grasses display most of those traits, their improper agronomic management can cause environmental burdens, either directly to the surrounding agroecosystem or indirectly elsewhere [5]. Agricultural practices thus need to be optimized according to the site-specific environmental conditions and crop requirements to maximize the net environmental benefit. 
The life cycle assessment (LCA) is a methodology widely used for the evaluation of the environmental burdens associated with bioenergy/biofuel production, by identifying energy and materials used as well as waste and emissions released to the environment [6]. Several LCAs studies have found a significant net reduction in greenhouse gas (GHG) emissions and fossil energy consumption with bioenergy crops replacing fossil fuels $[7,8]$. However, some also ascertained other impact categories, such as local air pollution, acidification, eutrophication, ozone depletion, and land use, among others [9,10], often concluding that many bioenergy crops might cause contamination of water and soil resources, mainly when irrigation, fertilizers, and pesticides are intensively used. Nonetheless, these environmental burdens are even more affected by site-specific assumptions than the GHG and energy balances, suggesting that it is not easy to draw simplified conclusions [11]. Further uncertainties might arise in geographical areas where agriculture systems are subjected to increasing pressure due to global warming, such as the Mediterranean. Indeed, the Mediterranean region has been identified as a climate change hot spot, with most countries already experiencing a rise in temperatures, freshwater scarcity, and high risk of prolonged drought $[12,13]$. In addition, semiarid climates in the Mediterranean are typically characterized by nutrient deficiency [14] and, as a result, substantial areas of agricultural land are already becoming marginal and often abandoned due to increasing dryness and fertility loss leading to bio-physical and socio-economic limitations [2,15]. On the other hand, cropping these lower grade lands with bioenergy crops might help to meet many sustainability requirements and ecosystem services, such as no direct competition with food/feed, limited iLUC, benefits to biodiversity, and reduction of erosion risks, among others [16]. However, tailored crops, input amount, and timely application, primarily of water and nitrogen, can in part enhance cropping system outcomes and restore rhizospheric microbial community functions for optimum productivity [14].

Previous studies have addressed input reduction to improve water and nutrient use efficiency in many bioenergy crops in the semiarid Mediterranean climate [17,18]. The present study focused on a three-year field trial, comparing two perennial grasses-namely, giant reed (Arundo donax L.) and miscanthus (Miscanthus $\times$ giganteus Greef et Deuter) under different soil water availability and nitrogen fertilization in a semiarid Mediterranean environment. The aim was to ascertain the biomass yield, the $\mathrm{CO}_{2}$-sequestration, and the life cycle assessment of biomass use for renewable heat production replacing fossil fuels.

\section{Materials and Methods}

\subsection{Agronomic Data}

Giant reed (Arundo donax L.) and miscanthus (Miscanthus $\times$ giganteus Greef et Deuter) were grown in Enna, Italy $\left(37^{\circ} 23^{\prime}\right.$ lat. N, $14^{\circ} 21^{\prime}$ long. E, $450 \mathrm{~m}$ a.s.l.), in a deep, loam soil for three consecutive growing seasons. Field and bed preparation followed an autumn ploughing at $30 \mathrm{~cm}$ depth and a spring disc-harrowing at $20 \mathrm{~cm}$ depth before transplant. Rhizomes were mechanically transplanted in spring 2002, at a depth of $0.15 \mathrm{~m}$ and at a density of 20,000 rhizomes ha ${ }^{-1}$ for both species.

Throughout the three-year experimental period, two levels of nitrogen $(\mathrm{N})$ fertilizationnamely, $50 \mathrm{~kg} \mathrm{~N} \mathrm{ha}^{-1}\left(\mathrm{~N}_{50}\right)$ and $100 \mathrm{~kg} \mathrm{~N} \mathrm{ha}^{-1}\left(\mathrm{~N}_{100}\right)$-and two levels of soil water availability - namely, $25 \%$ and $75 \%$ of maximum evapotranspiration restoration $\left(\mathrm{I}_{25}\right.$ and $\mathrm{I}_{75}$, respectively)—were differentiated. Crops were grown in a split-split plot experimental design with three replications, where the species was the main plot $(12 \mathrm{~m} \times 4 \mathrm{~m})$, the irrigation the subplot $(6 \mathrm{~m} \times 4 \mathrm{~m})$, and the $\mathrm{N}$ fertilization the sub-sub plot $(3 \mathrm{~m} \times 4 \mathrm{~m})$. The $\mathrm{N}$ fertilization was applied at the beginning of each growing season as ammonium nitrate $(27 \%)$, while a basal dressing with $120 \mathrm{~kg} \mathrm{P}_{2} \mathrm{O}_{5} \mathrm{ha}^{-1}$ as superphosphate (18\%) was applied in the establishment year. Irrigation water was supplied by means of a drip system during summer months according to the water balance method $[17,18]$. The irrigation volume in $\mathrm{I}_{25}$ was $115 \mathrm{~mm}, 146 \mathrm{~mm}$, and $150 \mathrm{~mm}$ in both species in the first, second and third growing seasons, while $\mathrm{I}_{75}$ received $441 \mathrm{~mm}, 438 \mathrm{~mm}$, and $450 \mathrm{~mm}$, respectively. Aboveground biomass was harvested in wintertime in representative subplots of $6 \mathrm{~m}^{2}$ for 
all species, treatments, and replications. Biomass subsamples were placed in a ventilated oven at $65{ }^{\circ} \mathrm{C}$, up to a constant weight, for dry matter determination.

The $\mathrm{CO}_{2}$-sequestration $\left(\mathrm{Mg} \mathrm{ha}^{-1}\right)$ was calculated according to the aboveground biomass yield $(\mathrm{Y})$, the biomass carbon content $(\mathrm{C} \%)$, and the conversion of $\mathrm{C}$ to $\mathrm{CO}_{2-}$ equivalent:

$$
\mathrm{CO}_{2} \text {-sequestration }=[(\mathrm{Y} \times \mathrm{C}) \times(44 / 12)]
$$

where: $\mathrm{Y}=$ dry biomass yield $\left(\mathrm{Mg} \mathrm{ha}^{-1}\right) ; \mathrm{C}=$ carbon content of miscanthus and giant reed biomass of $45.7 \%$ and $45.3 \%$, respectively [19]; $44=\mathrm{CO}_{2}$-equivalent atomic weight; $12=$ carbon atomic weight; and $16=$ the oxygen atomic weight.

The maximum and minimum air temperature and rainfall were measured by a weather station connected to a data logger (CR 10, Campbell Scientific, Logan, UT, USA). The reference crop evapotranspiration $\left(\mathrm{ET}_{0}\right)$ was calculated from the class A evaporation pan $(\mathrm{mm})$ by the pan coefficient of 0.80 [20]. Equipment were set-up nearby the experimental field and daily data were aggregated on ten-day basis.

\subsection{Life Cycle Assessment}

The LCA followed the ISO standards 14040 and 14044 guidelines [21,22]. The impact on the environment of the solid biomass from giant reed and miscanthus in a combustion boiler to produce heat for domestic use was compared to the impact of a fossil fuel for heat production and use. The life cycle of the biogenic system included soil tillage and bed preparation, nursery activities for rhizome fragmentation and establishment, cropping system differentiation (i.e., nitrogen fertilization rates, and irrigation levels), biomass harvest, logistics, conversion, use phase, and end of life (residual ash). The life cycle of the conventional reference system included crude oil extraction, processing, transportation, use phase, and end of life.

The reference unit was the thermal energy in MJ of energy produced. The primary energy consumption $\left(\mathrm{MJ} \mathrm{h}^{-1}\right)$ and emissions $\left(\mathrm{g} \mathrm{h}^{-1}\right)$ for each specific operation were obtained by multiplying the time of resource use by the amount of input, according to the database of the Institute for Energy and Environmental Research [23].

Although the lifespan of perennial grasses is fifteen years or more [24], the LCA was conducted for the establishment, second, and third growing season separately. For each crop and treatment, farming energy input (both direct and indirect) were acquired by Mantineo et al. [25] because the current data came from the same field experiment.

The reference cropping system considered in this work is a grass-fallow in which the agronomic management was defined by a first soil tillage (ploughing and harrowing) and two mowing operations per year.

Field emissions from the use of fertilizers included nitrous oxide $\left(\mathrm{N}_{2} \mathrm{O}\right)$, nitric oxide (NO), and ammonia $\left(\mathrm{NH}_{3}\right)$ in the atmosphere, and nitric ions $\left(\mathrm{NO}_{3}^{-}\right)$and orthophosphoric acid $\left(\mathrm{H}_{3} \mathrm{PO}_{4}\right)$ in surface and subsurface waters.

The multivariate empirical models developed by Bouwman et al. [26] were used for the assessment of direct $\mathrm{NO}_{2}$ and $\mathrm{NO}$ :

$$
\mathrm{NO}_{2}=e^{\text {Constant }+\left(\sum \text { factor class }\right)}
$$

where the constant is -0.4136 and the coefficients for factor classes are the fertilizer type (ammonium nitrate, 0.0061 ) by $\mathrm{N}$ rate, the crop type (grass, -1.268 ), the soil texture (medium, -0.472$)$, the soil drainage (good, -0.420$)$, the soil $\mathrm{pH}(>7.3,-0.352)$, the climate (temperate, 0 ) and the length of experiment ( $>300$ days, 0.825$)$.

$$
\mathrm{NO}=e^{\text {Constant }+\left(\sum \text { factor class }\right)}
$$

where the constant is -1.527 and the coefficients for factor classes are the fertilizer type (ammonium nitrate, 0.0040 ) by $\mathrm{N}$ rate, and the soil drainage (good, 0.946 ). 
The $\mathrm{NH}_{3}$ emissions were estimated according to Bouwman et al. [27]:

$$
\mathrm{NH}_{3}=e^{\left(\sum \text { factor class }\right)}
$$

where the factor classes are the crop type (grass, -0.158 ), the fertilizer type and amount (ammonium nitrate $\leq 50 \mathrm{~kg}, 0.134 ; \leq 100 \mathrm{~kg}, 1.936$ ), the application mode (broadcast, -1.305 ), and the soil drainage (good, 0.946).

The amount of indirect emissions can be converted to $\mathrm{NO}_{2}$ emission by multiplying $\mathrm{NO}$ and $\mathrm{NH}_{3}$ emissions by the default value $0.01[28,29]$.

$\mathrm{NO}_{3}$-leaching was calculated according to the semi-empirical model of $\mathrm{Di}$ and Cameron [30] considering volatilization and denitrification:

$$
\mathrm{NO}_{3}=0.00143\left(\mathrm{~N}_{\mathrm{PL}}\right)^{2}-0.0229 \mathrm{~N}_{\mathrm{PL}}
$$

where 0.00143 and -0.0229 are regression coefficients and $\mathrm{N}_{\mathrm{PL}}$ is the nitrogen (predominantly $\mathrm{NO}_{3}$ ) potentially leached ( $\mathrm{kg} \mathrm{N} \mathrm{ha}^{-1} 100 \mathrm{~mm}^{-1}$ drainage).

The emission factor of $0.33 \%$ per $\mathrm{kg} \mathrm{P}$ applied has been assumed for phosphates leached to surface and subsurface waters [31].

Heavy metals emissions (cadmium, chromium, copper, iron, lead, manganese, mercury, nickel, selenium, and zinc) were calculated according to the share in fertilizers, in vegetable biomass, for the heavy metals naturally occurring in the soil and those from atmospheric depositions [23].

In the industrial phase, the hourly unit emissions of the bioconversion for the production of thermal energy - which includes the transport, storage, combustion, and the treatment of residual ashes-were considered. The carbon dioxide $\left(\mathrm{CO}_{2}\right)$ emissions at the biomass combustion stage were set to zero due to the $\mathrm{CO}_{2}$ uptake from the atmosphere by the crop photosynthetic process.

The relative emissions $\left(\mathrm{g} \mathrm{h}^{-1}\right)$ were determined for each sub-phase, taking into account the hourly use of each equipment and the production means of the heating system. The emission values, referred to one hectare ( $\mathrm{MJ} \mathrm{ha}^{-1} ; \mathrm{g} \mathrm{ha}^{-1}$ ), were converted to the unit of energy produced ( $\mathrm{MJ} \mathrm{MJ}^{-1} ; \mathrm{g} \mathrm{MJ}^{-1}$ ). The biomass moisture content and the lower heating value were set at $15 \%$ and $15.6 \mathrm{MJ} \mathrm{kg}^{-1}$ for both crops [20] and the thermal bioconversion efficiency at $90 \%$.

The conventional reference system was based on fossil fuel oil for the production of thermal energy resulting from the refining of oil, which is imported into Europe from the OPEC countries.

The impact assessment followed the classification that grouped emissions into specific impact categories represented by the consumption of abiotic resources and linked them to the emissions of chemical substances.

The consumption of abiotic resources category included the set of primary energy resources used for each production process. Each production means used was characterized by a total energy cost $\left(\mathrm{E}_{1}\right)$, given by the sum of an operating energy cost and a depreciation cost, expressed in $\mathrm{MJ} \mathrm{h}^{-1}$, which derived from the sum of primary energy resources (crude oil, coal, lignite, natural gas, uranium) and abiotic resources (water), which entered its production process or during its use, as:

$$
\mathrm{E}_{1}=\mathrm{RE} / \mathrm{HU} \times \mathrm{LHV}
$$

where RE = sum of the energy resources used for the production or use of the means $(\mathrm{kg}) ; \mathrm{HU}=$ technical life of the machine (hours); LHV = lower heating value $\left(\mathrm{MJ} \mathrm{kg}^{-1}\right)$ : 45.6 for crude oil, 48.8 for natural gas, 19.0 for hard coal, 9.5 for lignite, and 451,000 for uranium [32].

The greenhouse effect category included carbon dioxide and monoxide $\left(\mathrm{CO}_{2}\right.$ and $\left.\mathrm{CO}\right)$, methane $\left(\mathrm{CH}_{4}\right)$, nitrous oxide $\left(\mathrm{N}_{2} \mathrm{O}\right)$, and volatile organic compounds (VOC). According to the Intergovernmental Panel on Climate Change (IPCC), the equivalence factor is expressed 
as $\mathrm{g} \mathrm{CO}_{2} \mathrm{~kg}^{-1}[33,34]$. The time horizon to which the greenhouse effect was referred was 100 years.

The potential depletion of the stratospheric ozone layer considered only the nitrous oxide $\left(\mathrm{N}_{2} \mathrm{O}\right)$ emissions for this impact category.

The gases that contribute to the acidification effect of the atmosphere are ammonia $\left(\mathrm{NH}_{3}\right.$ in the gaseous form in the air and $\mathrm{NH}_{4+}$ in the ionic form in water), hydrogen chloride $(\mathrm{HCl})$, nitrogen oxides $\left(\mathrm{NO}_{\mathrm{x}}\right)$, and sulphur dioxide $\left(\mathrm{SO}_{2}\right)$, all expressed in $\mathrm{g}$ $\mathrm{SO}_{2}$-equivalent [35].

For the eutrophication of water bodies, the effects of ammonia $\left(\mathrm{NH}_{3}\right.$ and $\left.\mathrm{NH}_{4+}\right)$, nitrogen oxides $\left(\mathrm{NO}_{\mathrm{x}}\right)$, nitrates $\left(\mathrm{NO}_{3-}\right)$, and phosphates $\left(\mathrm{PO}_{4}{ }^{3-}\right)$ were aggregated and expressed in $\mathrm{g} \mathrm{NO}_{3}$ - per $\mathrm{g}$ of substance [36].

We normalised all results by relating them to the environmental situation in Europe; i.e., by dividing them by the annual average resource demand and the average emissions of various substances per capita in Europe [6]. The results were thus expressed in so-called inhabitant equivalents per $100 \mathrm{TJ}$ of energy consumed in one year. This way, the relative magnitude of the results could be better interpreted. Due to the uncertainty related to future emissions of various substances, inhabitant equivalents were calculated based on the year 2000 values. Despite the representativeness of the collected agronomic data in terms of temporal and geographical correlation (data collected within 3 years from the study and from the same area) [37], our assumptions about the post-harvest and technological uses might have caused uncertainties. An assessment of uncertainty was not performed; nonetheless, in order to avoid biased comparisons, mature technologies were taken as a basis for the assessment, and discussions about the main source of uncertainties took expert judgments into account. According to the goal of the present study and the system boundaries, the highest priority was given to the greenhouse gas emission savings resulting from better agronomic practices to maximize yield, which in turn determined the amount of conventional products that could be substituted within the used area.

\subsection{Statistical Analysis}

Data were subjected to the two-way analysis of variance (ANOVA) using repeated measurements in time (SPSS, PASW Statistics 18). Measurements were performed throughout growing seasons within-subjects, while species, irrigation, and nitrogen fertilization as between-subjects. When data failed Mauchly's sphericity test, the univariate results were adjusted by using the Greenhouse-Geisser Epsilon and the Huynh-Feldt Epsilon correction factors. When univariate results satisfied sphericity tests for within-subjects effects, the $F$-values and associated $p$-values for between-subjects effects were tested. The Duncan's post-hoc test was used for mean separation at a 95\% confidence level.

\section{Results}

\subsection{Meteorological Conditions}

The crop establishment was accomplished in mid-March, when mean air temperature was consistently higher than $10^{\circ} \mathrm{C}$ (Figure 1). After the establishment, an even rainfall distribution was observed up to May, thereafter a long dry period with high reference evapotranspiration $\left(\mathrm{ET}_{0}\right)$ was registered in summertime. The first growing season was untypically dry with only $334 \mathrm{~mm}$ of rainfall throughout the whole growing season. The first biomass harvest was conducted in March 2003, then stem re-sprouting for the second growing season coincided with the increase in air temperatures in spring. 


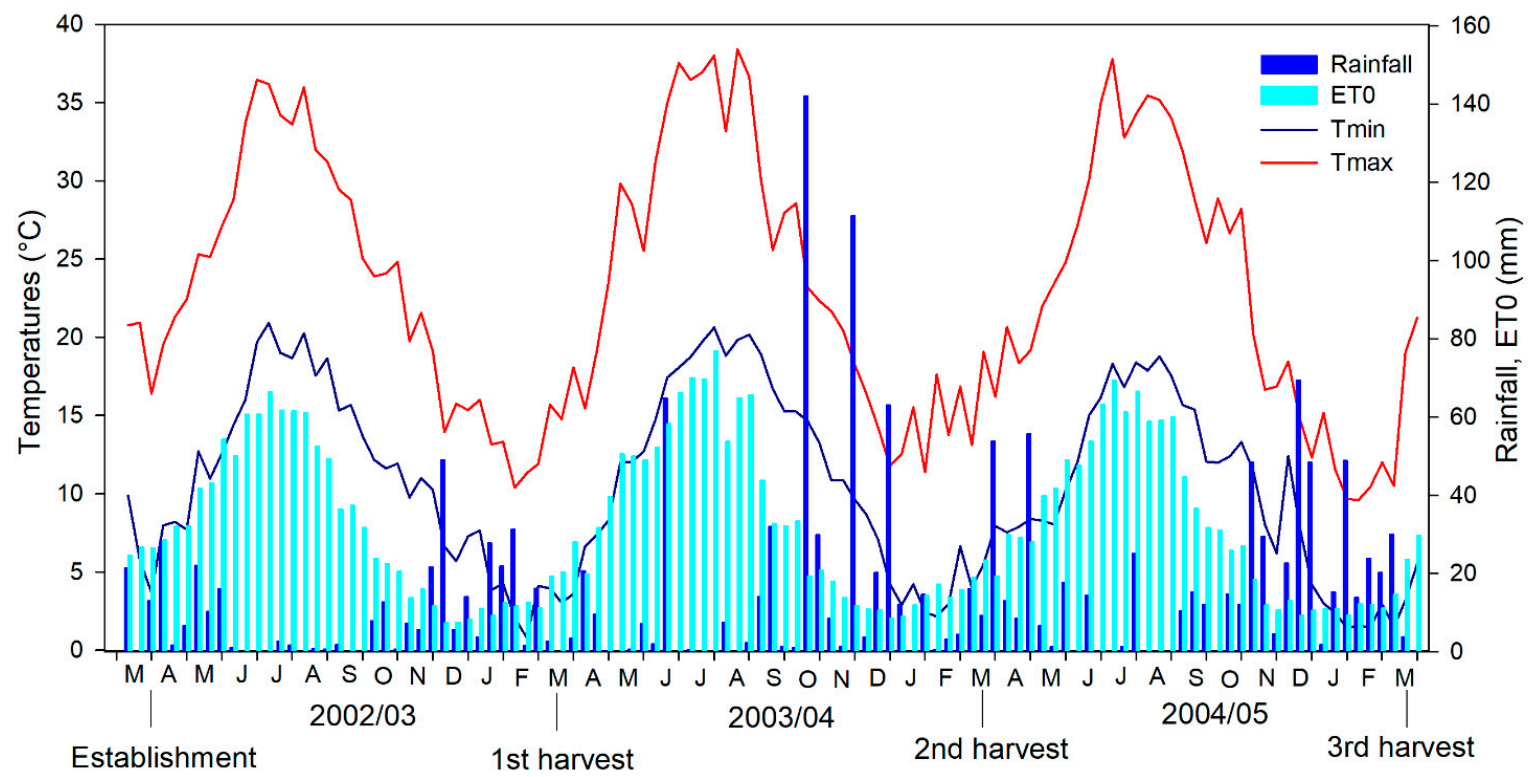

Figure 1. Meteorological trends, maximum (Tmax) and minimum (Tmin) air temperature $\left({ }^{\circ} \mathrm{C}\right)$, rainfall and reference evapotranspiration $\left(\mathrm{ET}_{0}, \mathrm{~mm}\right)$ at the experimental site $\left(37^{\circ} 23^{\prime}\right.$ lat. $\mathrm{N}, 14^{\circ} 21^{\prime}$ long. $\mathrm{E}, 450 \mathrm{~m}$ a.s.1.) during 2002/03, 2003/04, and 2004/05 growing seasons.

The second growing season was particularly hot and dry in the summertime, with very high $\mathrm{ET}_{0}$ (nearly $7.5 \mathrm{~mm}$ per day) and air temperature close to $38^{\circ} \mathrm{C}$ without significant rain events, except in late September and throughout the autumn. The rainfall in the whole growing season was $605 \mathrm{~mm}$, of which $43 \%$ was registered from October to November. The second season biomass harvest was carried out in March 2004; thereafter, the third growing season started with stem re-sprouting in spring.

The third growing season had a quite even rainfall distribution (28\% in spring, $32 \%$ in autumn, and $32 \%$ in winter), except in the summertime when only $8 \%$ out of $650 \mathrm{~mm}$ of the whole growing season was registered. The air temperature, both maximum and minimum, was cooler than the previous growing season, notably the minimum air temperature from the end of December up to the biomass harvest time was the lowest of the overall experimental period.

The whole season $\mathrm{ET}_{0}$ was $1152 \mathrm{~mm}$ in 2002/03, $1245 \mathrm{~mm}$ in 2003/04, and $1174 \mathrm{~mm}$ in $2004 / 05$, and the mean air temperature was $16.8^{\circ} \mathrm{C}, 17.4{ }^{\circ} \mathrm{C}$, and $16.2^{\circ} \mathrm{C}$, respectively. The irrigation, at the planned amount $\left(\mathrm{I}_{25}\right.$ and $\left.\mathrm{I}_{75}\right)$, was scheduled in summertime, approximately from the end of May to the beginning of September, when the highest crop water demand coincided with the dry period in this environment.

\subsection{Biomass Yield and Aboveground $\mathrm{CO}_{2}$-Sequestration}

The ANOVA showed that the species and irrigation main effects on biomass yield and $\mathrm{CO}_{2}$-sequestration were significant. The harvest, which represented the within-subject effect, was also significant, while neither the fertilization nor the interactions were (Table 1). 
Table 1. Repeated measures ANOVA for main effects and interactions on aboveground dry matter yield (DMY) and aboveground $\mathrm{CO}_{2}$-sequestration of Arundo donax and Miscanthus $\times$ giganteus. Degrees of freedom (DF) adjusted mean square (Adj MS) and significance: $p \leq 0.001\left(^{* * *}\right)$, not significant $\left({ }^{\mathrm{ns}}\right)$.

\begin{tabular}{cccc}
\hline \multirow{2}{*}{ Source } & DF & DMY & CO $_{2}$-Sequestration \\
\cline { 3 - 4 } & & \multicolumn{2}{c}{ Adj MS } \\
\hline Harvest & 2 & $5427.01^{* * *}$ & $15,079.6^{* * *}$ \\
Species (S) & 1 & $2259.60^{* * *}$ & $6088.6^{* * *}$ \\
Irrigation (I) & 1 & $530.46^{* * *}$ & $1476.2^{* * *}$ \\
Fertilization (F) & 1 & $26.49^{\mathrm{ns}}$ & $73.1^{\mathrm{ns}}$ \\
S $\times$ I & 1 & $0.20^{\mathrm{ns}}$ & $0.30^{\mathrm{ns}}$ \\
S $\times \mathrm{F}$ & 1 & $21.51^{\mathrm{ns}}$ & $59.4^{\mathrm{ns}}$ \\
$\mathrm{I} \times \mathrm{F}$ & 1 & $3.53^{\mathrm{ns}}$ & $9.8^{\mathrm{ns}}$ \\
$\mathrm{S} \times \mathrm{I} \times \mathrm{F}$ & 1 & $1.49^{\mathrm{ns}}$ & $4.1^{\mathrm{ns}}$ \\
Error & 62 & 33.99 & 93.5 \\
\hline
\end{tabular}

Mean separation of main effects indicated that giant reed outperformed miscanthus across fertilization and irrigation levels (26.1 and $14.9 \mathrm{Mg} \mathrm{ha}^{-1}$, respectively). The irrigation $\mathrm{I}_{25}$ was significantly lower than $\mathrm{I}_{75}$ across species and fertilization $\left(17.8\right.$ and $23.2 \mathrm{Mg} \mathrm{ha}^{-1}$, respectively), while fertilization, although higher in $\mathrm{N}_{100}$ than $\mathrm{N}_{50}$, across the average of the other factors (18.9 and $21.1 \mathrm{Mg} \mathrm{ha}^{-1}$, respectively), was not different (Figure 2).

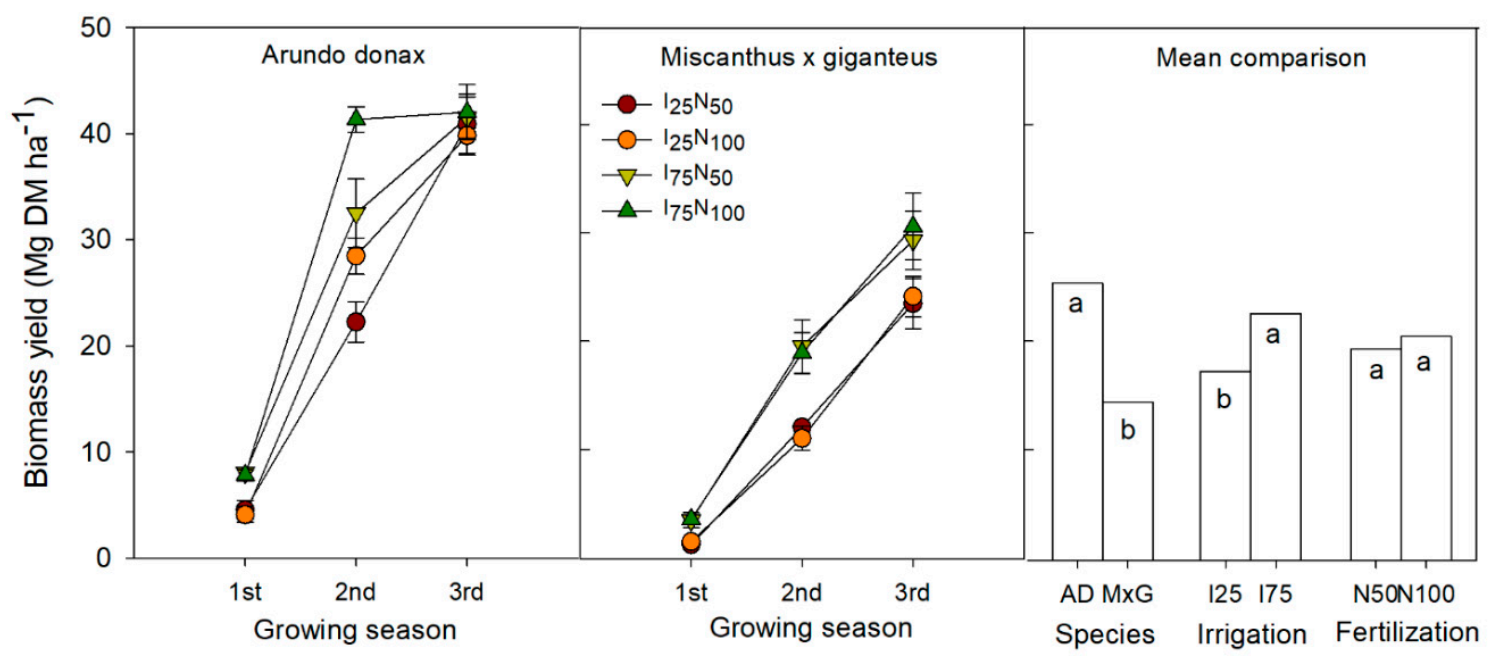

Figure 2. Biomass dry matter yield $\left(\mathrm{Mg} \mathrm{DM} \mathrm{ha}^{-1}\right)$ of Arundo donax and Miscanthus $\times$ giganteus throughout the experimental period and mean separation of main effects according to the Duncan's post-hoc test. Different letters within main effect indicate statistical different mean $(p \leq 0.05)$.

Biomass yield increased from the first to the third growing season, and the increase was much more apparent in miscanthus, which followed a linear trend, irrespective of nitrogen and irrigation levels. Nonetheless, yield response seemed more affected by the irrigation than by the nitrogen. The highest yields in miscanthus were observed in the third year in $\mathrm{I}_{75} \mathrm{~N}_{100}$ and $\mathrm{I}_{75} \mathrm{~N}_{50}$ (30.6 and $29.3 \mathrm{Mg}$ ha $^{-1}$, respectively), while reduction of the irrigation decreased the biomass yield to 23.5 and $24.1 \mathrm{Mg}^{-1}\left(\mathrm{I}_{25} \mathrm{~N}_{100}\right.$ and $\mathrm{I}_{25} \mathrm{~N}_{50}$, respectively). Giant reed increased the biomass yield almost linearly in the lowest input combination $\left(\mathrm{I}_{25} \mathrm{~N}_{50}\right)$, while increasing input levels, particularly irrigation, boosted yield response from the second growing season to the third one, where biomass yield levelled off irrespective of the input supplied. The highest input combination in giant reed $\left(\mathrm{I}_{75} \mathrm{~N}_{100}\right)$ boosted biomass yield from $9 \mathrm{Mg} \mathrm{ha}^{-1}$ at the first to $41 \mathrm{Mg} \mathrm{ha}^{-1}$ at the second harvest, levelling off thereafter. 
The aboveground $\mathrm{CO}_{2}$-sequestration $\left(\mathrm{CO}_{2}\right.$-equivalent) was very low in miscanthus but also in giant reed under the lowest irrigation level. From the second growing season onward, the $\mathrm{CO}_{2}$-sequestration increased in both species and it was proportional to the input supplied in giant reed in the second season $\left(\mathrm{I}_{75} \mathrm{N1}_{00}>\mathrm{I}_{75} \mathrm{~N}_{50}>\mathrm{I}_{25} \mathrm{~N}_{100}>\mathrm{I}_{25} \mathrm{~N}_{50}\right)$, while no differences were observed in the third year, where the $\mathrm{CO}_{2}$ - sequestration averaged $68 \mathrm{Mg} \mathrm{ha}^{-1}$ (Figure 3).

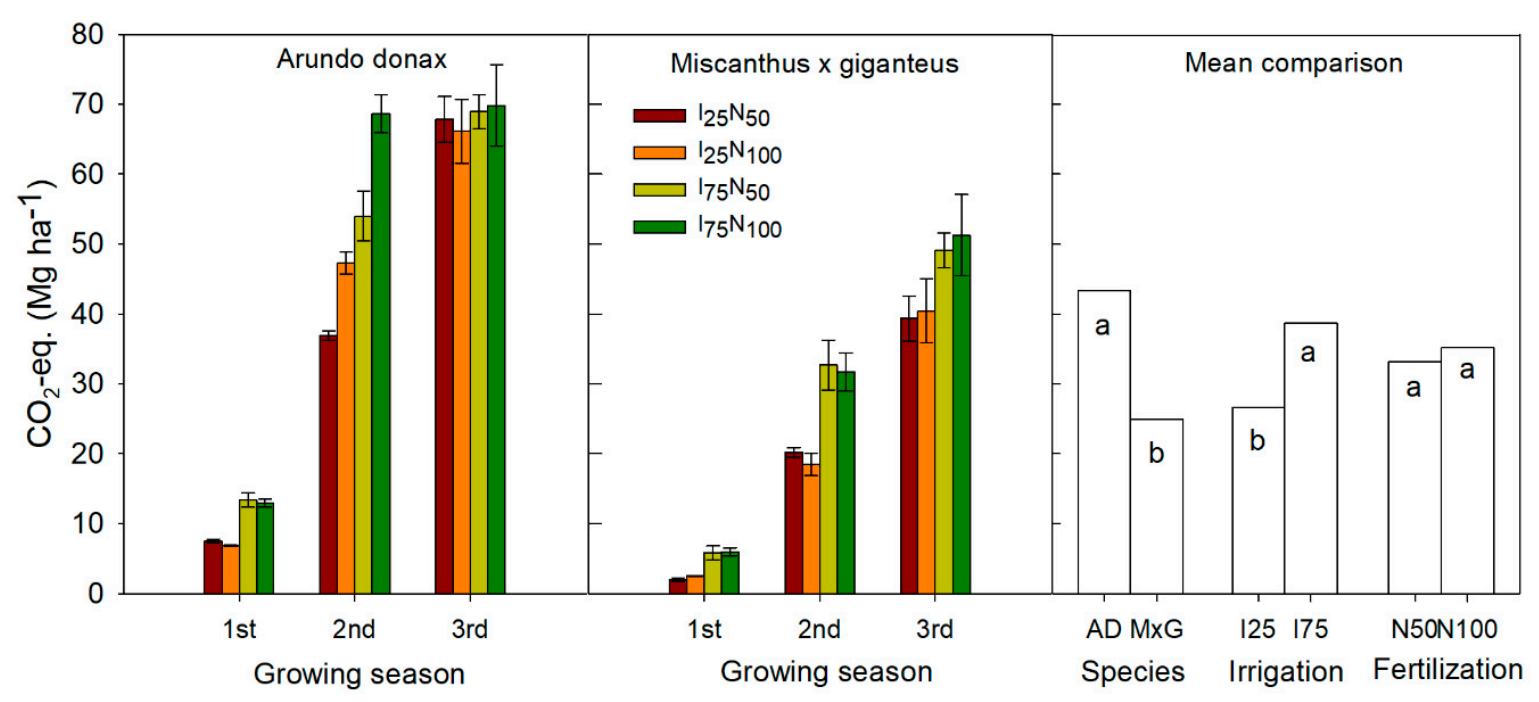

Figure 3. Aboveground $\mathrm{CO}_{2}$-sequestration $\left(\mathrm{CO}_{2}\right.$-equivalent, $\mathrm{Mg}$ ha $\left.{ }^{-1}\right)$ of Arundo donax and Miscanthus $\times$ giganteus throughout the experimental period and mean separation of main effects according to the Duncan's post-hoc test. Different letters within main effect indicate statistical different mean $(p \leq 0.05)$.

In miscanthus, the $\mathrm{CO}_{2}$-sequestration was different between irrigation levels both in the second and third growing seasons, with the $\mathrm{I}_{75}$ always higher than $\mathrm{I}_{25}$, but the fertilization did not improve it. Across the average of experimental factors, giant reed had a significantly higher $\mathrm{CO}_{2}$-sequestration than miscanthus (43.4 and $24.9 \mathrm{Mg} \mathrm{ha}^{-1}$ ), and $\mathrm{I}_{75}$ was higher than $\mathrm{I}_{25}\left(38.7\right.$ and $26.6 \mathrm{Mg} \mathrm{ha}^{-1}$ ). Fertilization $\mathrm{N}_{100}$ enhanced of only $1.9 \mathrm{Mg} \mathrm{ha}^{-1}$ the $\mathrm{CO}_{2}$-equivalent as compared with the $\mathrm{N}_{50}$.

\subsection{Life Cycle Assessment}

The ANOVA showed a significant effect of the species on all impact categories. The irrigation was significant for all categories, except for the non-renewable energy use (NREU). The fertilization was significant only for the ozone depletion (OD) and the eutrophication (EU). The harvest, which represented the within-subject effect, was also significant in all impact categories, while no significant interactions of main effects occurred (Table 2).

Table 2. Repeated measures ANOVA for main effects and interactions on impact categories of Arundo donax and Miscanthus $\times$ giganteus. Degree of freedom (DF), adjusted mean square (Adj MS), and significance: $p \leq 0.001\left(^{* * *}\right), p \leq 0.01\left(^{* *}\right), p \leq 0.05$ $\left({ }^{*}\right)$, not significant $\left({ }^{\text {ns }}\right)$.

\begin{tabular}{|c|c|c|c|c|c|c|}
\hline \multirow{2}{*}{ Source } & \multirow{2}{*}{ DF } & NREU & GWP & OD & $\mathrm{AC}$ & EU \\
\hline & & \multicolumn{5}{|c|}{ Adj MS } \\
\hline Harvest & 2 & $697,594^{* * *}$ & $1,714,927^{* * *}$ & $15,174,406^{* * *}$ & $2,975,953^{* * *}$ & $3,713,964^{* * *}$ \\
\hline Species (S) & 1 & $157,300 * *$ & $371,154 * *$ & $1,175,013 * *$ & $567,909 * * *$ & $743,625^{* * *}$ \\
\hline Irrigation (I) & 1 & $39,919^{\mathrm{ns}}$ & 189,045 * & $1,271,968 * *$ & $359,438 * *$ & $462,952 * *$ \\
\hline Fertilization (F) & 1 & $6637 \mathrm{~ns}$ & $72,523^{\mathrm{ns}}$ & $106,865^{* *}$ & $25,114^{\mathrm{ns}}$ & $11,859 *$ \\
\hline $\mathrm{S} \times \mathrm{I}$ & 1 & $24,204^{\mathrm{ns}}$ & 72,719 ns & $3888^{\text {ns }}$ & $126,065^{\text {ns }}$ & $165,414^{\mathrm{ns}}$ \\
\hline $\mathrm{S} \times \mathrm{F}$ & 1 & $178.0^{\mathrm{ns}}$ & $839.2^{\mathrm{ns}}$ & $195,575^{\mathrm{ns}}$ & $727.5^{\text {ns }}$ & $3191^{\mathrm{ns}}$ \\
\hline $\mathrm{I} \times \mathrm{F}$ & 1 & $83.2^{\mathrm{ns}}$ & $4284.1^{\mathrm{ns}}$ & $83,364^{\mathrm{ns}}$ & $253.4^{\mathrm{ns}}$ & $70.4^{\mathrm{ns}}$ \\
\hline $\mathrm{S} \times \mathrm{I} \times \mathrm{F}$ & 1 & $712.1^{\mathrm{ns}}$ & $277.6^{\text {ns }}$ & $5819.9^{\mathrm{ns}}$ & $3039.2^{n s}$ & $5881^{\mathrm{ns}}$ \\
\hline Error & 62 & 10,987 & 27,258 & 130,675 & 42,094 & 54,596 \\
\hline
\end{tabular}


The three experimental years showed environmental benefits of the biogenic system for the impact categories non-renewable energy use (NREU) and global warming potential (GWP). On the contrary, environmental burdens were observed for the ozone depletion (OD), acidification (AC), and eutrophication (EU). Burdens were also registered in miscanthus $\mathrm{I}_{25} \mathrm{~N}_{100}$ and $\mathrm{I}_{25} \mathrm{~N}_{50}$ in the first growing season for the GWP impact category (Figure 4).

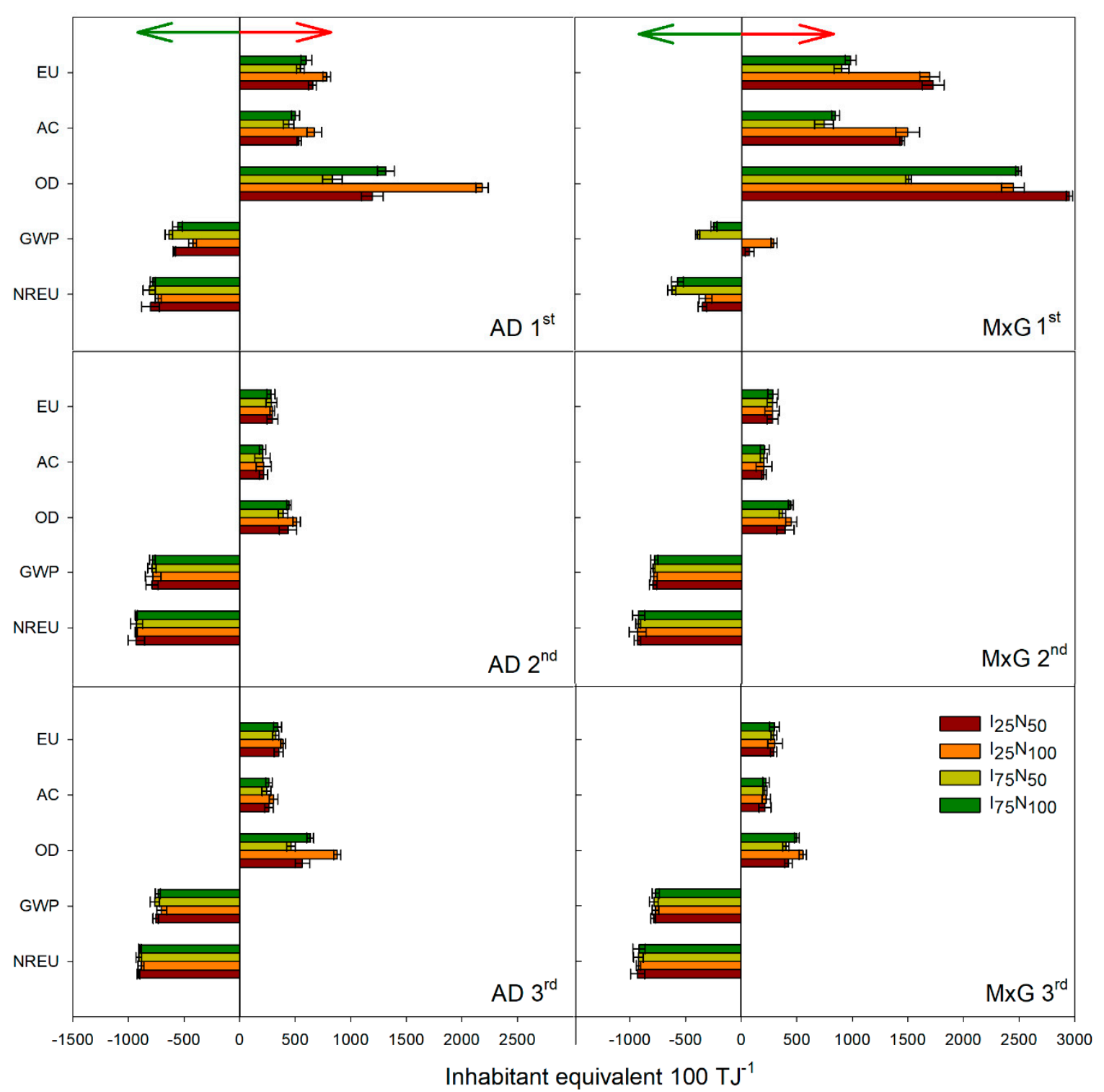

Figure 4. Impact categories (NREU—non-renewable energy use; GWP—global warming potential; OD—ozone depletion; AC-acidification; EU-eutrophication), expressed in European inhabitant equivalent per $100 \mathrm{TJ}$ of energy consumed in one year, of Arundo donax and Miscanthus $\times$ giganteus throughout the experimental period and investigated main effects (green arrow-environmental benefits; red arrow-environmental burdens).

Environmental burdens were higher in the first than in the second and third years in both species. Environmental benefits were also more contained in the first than in the second and the third growing seasons.

In the first growing season, giant reed $\mathrm{I}_{75} \mathrm{~N}_{50}$ showed the best combination for both benefits and burdens, while the worst was in $\mathrm{I}_{25} \mathrm{~N}_{100}$. Miscanthus $\mathrm{I}_{25} \mathrm{~N}_{50}$ and $\mathrm{I}_{25} \mathrm{~N}_{100}$ showed the worst combination for all impact categories in the first growing season, while the $\mathrm{I}_{75} \mathrm{~N}_{50}$ was the best. 
Within the same species, combination of experimental factors showed very similar results for all impact categories in the second growing season. In the third, the benefits were also similar between species and input combinations, while within species, the burdens were higher in the case of giant reed $\mathrm{I}_{25} \mathrm{~N}_{100}$ for the OD and $\mathrm{EU}$ and in the case of miscanthus $\mathrm{I}_{25} \mathrm{~N}_{100}$ for OD.

Across the average of experimental factors, the mean separation showed a greater performance of giant reed than miscanthus, with higher benefits and lower burdens of impact categories investigated (Table 3). Increasing irrigation, across species and fertilization, worsened the GWP, the OD, the AC, and the EU. Increasing the fertilization, across species and irrigation, worsened both the OD and the EU, while it was ineffective for the other impact categories.

Table 3. Mean separation of main effects on impact categories, expressed in European inhabitant equivalent per $100 \mathrm{TJ}$ of energy consumed in one year of Arundo donax and Miscanthus $\times$ giganteus grown under different irrigation levels $\left(\mathrm{I}_{25}\right.$ and $\left.\mathrm{I}_{75}\right)$ and nitrogen rates $\left(\mathrm{N}_{50}\right.$ and $\left.\mathrm{N}_{100}\right)$. Different letters within main effect indicate statistical different mean $(p \leq 0.05)$.

\begin{tabular}{cccccc}
\hline & NREU & GWP & OD & AC & EU \\
\hline Species & & & & & \\
Arundo & $-870.26 \mathrm{a}$ & $-691.44 \mathrm{a}$ & $820.45 \mathrm{~b}$ & $339.44 \mathrm{~b}$ & $429.16 \mathrm{~b}$ \\
$\begin{array}{c}\text { Miscanthus } \\
\text { Irrigation }\end{array}$ & $-776.78 \mathrm{~b}$ & $-547.85 \mathrm{~b}$ & $1075.95 \mathrm{a}$ & $517.06 \mathrm{a}$ & $632.42 \mathrm{a}$ \\
I25 & $-799.97 \mathrm{a}$ & $-568.40 \mathrm{~b}$ & $1081.12 \mathrm{a}$ & $498.91 \mathrm{a}$ & $610.98 \mathrm{a}$ \\
I75 & $-847.07 \mathrm{a}$ & $-670.89 \mathrm{a}$ & $815.29 \mathrm{~b}$ & $357.59 \mathrm{~b}$ & $450.61 \mathrm{~b}$ \\
Nitrogen & & & & & \\
N50 & $-833.12 \mathrm{a}$ & $-651.38 \mathrm{a}$ & $826.37 \mathrm{~b}$ & $409.57 \mathrm{a}$ & $507.96 \mathrm{~b}$ \\
N100 & $-813.92 \mathrm{a}$ & $-587.91 \mathrm{a}$ & $1070.03 \mathrm{a}$ & $446.92 \mathrm{a}$ & $553.62 \mathrm{a}$ \\
\hline
\end{tabular}

\section{Discussion}

The three-year experimental period was characterized by interannual variability of air temperature, rainfall, and evapotranspiration. Beside the air temperature increase from spring to reach maximum values in summertime, which sustained stem sprouting and rapid elongation of the perennial grasses, the evapotranspiration $\left(\mathrm{ET}_{0}\right)$ increased as well, while rainfall followed an opposite trend, decreasing strongly in summertime when crop water demand was the highest. Early/middle autumn is usually wet with suitable air temperatures for growth; however, the photoperiod triggers flowering in perennial grasses and, consequently, the crops suspend soil water uptake and start senescence to overwinter [36].

With regards to the climatic parameters measured, the first experimental year was the driest, the second season had the highest $\mathrm{ET}_{0}$ and air summer temperature, while the third was the most favourable, although the coldest in winter. The irrigation provided in summertime was calculated to cope with either $75 \%$ or $25 \%$ of the maximum crop ET in order to reduce this high energy input. According to previous results, the biomass yield followed an asymptotic pattern in giant reed as a function of crop water use; thus, it becomes clear that the yield response flattens at high soil water availability [17]. The nitrogen $(\mathrm{N})$ was supplied according to previous observations, where the $\mathrm{N}$ removed with the aboveground biomass ranged from 50 to $120 \mathrm{~kg} \mathrm{~N} \mathrm{ha}^{-1}$ (unpublished data). This agrees with Monti and Zegada-Lizarazu [38], who calculated a $\mathrm{N}$ removal of $117 \mathrm{Kg} \mathrm{N}^{-1} \mathrm{yr}^{-1}$ in giant reed fertilized at $160 \mathrm{~kg} \mathrm{~N} \mathrm{ha}^{-1} \mathrm{yr}^{-1}$. Giant reed half $\mathrm{N}$ fertilized $\left(80 \mathrm{~kg} \mathrm{~N} \mathrm{ha}^{-1} \mathrm{yr}^{-1}\right)$ removed $90 \mathrm{~kg} \mathrm{~N} \mathrm{ha}^{-1} \mathrm{yr}^{-1}$, while the $\mathrm{N}$ removal was $75 \mathrm{~kg} \mathrm{~N}^{-1} \mathrm{yr}^{-1}$ in unfertilized plots. Thus, the present experiment was designed according to the low-input cultivation system.

Crops that were established by rhizome fragments grew well and followed the typical yielding phase, namely increasing from the first to the second and further to the third year [24]. However, the best combination of irrigation and fertilization on biomass yield in giant reed was the $\mathrm{I}_{75} \mathrm{~N}_{100}$, which boosted biomass yield to the ceiling already in the 
second year. The other treatments that were somehow limited in $\mathrm{N}$ or irrigation took an additional year to reach the maximum biomass yield achieved in this study. In miscanthus, the input level did not change the yield response trend, and the biomass yield followed a linear increase, reaching the maximum only in the third year. No interaction of main effects was observed in both species; thus, the yield change was explained only by the irrigation rather than by the fertilization. This is particularly true for miscanthus because irrigation, irrespective of nitrogen fertilization, improved biomass production either at first, second, or third growing season. In the case of giant reed, the irrigation seemed more effective in the first two years, while its effect disappeared in the third. In the second year, the $\mathrm{N}$ effect was somehow noteworthy in the case of giant reed; however, $\mathrm{N}$ was ineffective in the third year as well. Similar results had been already observed, where the nitrogen use efficiency became not significant in the third growing season of giant reed [17].

In accordance with other studies in the Mediterranean environment, giant reed outperformed miscanthus across the range of growing seasons, irrigation, and fertilization levels $[24,25]$.

The low productivity of perennial grasses in the establishment year is a well-known drawback $[39,40]$. This led to a very low $\mathrm{CO}_{2}$-sequestration, particularly in miscanthus in all input combinations, but also in giant reed $\mathrm{I}_{25} \mathrm{~N}_{100}$ and $\mathrm{I}_{25} \mathrm{~N}_{50}$. However, from the second growing season, the $\mathrm{CO}_{2}$-sequestration was quite high and ranged from 37 to $68 \mathrm{Mg} \mathrm{ha}^{-1}$ in giant reed and from 18 to $32 \mathrm{Mg} \mathrm{ha}^{-1}$ in miscanthus. The $\mathrm{CO}_{2}$-sequestration was proportional to the input supplied in giant reed in the second year, while no input effect was observed in the third one. On the contrary, the $\mathrm{CO}_{2}$-sequestration was mostly affected by the irrigation rather than by the fertilization in miscanthus, in both the second and the third year. Other studies with miscanthus showed a maximum $\mathrm{CO}_{2}$-sequestration up to $30.6 \mathrm{Mg} \mathrm{CO}_{2} \mathrm{ha}^{-1} \mathrm{yr}^{-1}$ in good soil conditions in Central Europe, while $19.2 \mathrm{Mg}$ $\mathrm{CO}_{2} \mathrm{ha}^{-1} \mathrm{yr}^{-1}$ and $24.0 \mathrm{Mg} \mathrm{CO}_{2} \mathrm{ha}^{-1} \mathrm{yr}^{-1}$ were achieved on marginal sites limited by cold or drought [41]. In this study, a positive linear relationship was found between $\mathrm{CO}_{2}$ sequestration and biomass yield ( $y=1.66 x+0.1028, R^{2}=0.99$, data not shown), meaning that each ton of lignocellulosic biomass could save up to $1.66 \mathrm{Mg} \mathrm{CO}_{2}$-equivalent ha ${ }^{-1}$.

The life cycle assessment showed large environmental benefits of the renewable source in two impact categories - namely, NREU, and GWP-after normalisation on the average European inhabitant equivalent. In this case, the amount of fossil fuels saved was equal to the amount that nearly 870 (giant reed) or 776 (miscanthus) European citizens would consume on average per $100 \mathrm{TJ}$ of heat in one year. The GWP avoided would be nearly 690 inhabitants equivalent for giant reed and 547 for miscanthus.

Benefits were a function of biomass yield, as indicated by the growing season effect in both species. The low biomass yield at the first harvest reduced NREU and GWP benefits in both species, and even environmental burdens were associated with miscanthus under reduced irrigation and high fertilization dose $\left(\mathrm{I}_{25} \mathrm{~N}_{100}\right)$ for the GWP impact category. The irrigation supply had a significant effect on GWP across species and fertilization treatments, so increasing the irrigation volume would increase the $\mathrm{g} \mathrm{CO}_{2}$-equivalent saved leading to GWP. Although the nitrogen had no significant effect, decreasing the $\mathrm{N}$ dose $\left(\mathrm{N}_{50}\right)$ would increase by 20 and 62 inhabitant equivalents the NREU and GWP, respectively.

Environmental burdens of the renewable source, compared to fossil fuels, were registered for the OD, AC, and EU. Even in this case, burdens were greater in the first year due to lower biomass yield and higher input used (e.g., soil tillage and bed preparation, nursery activities for rhizome fragmentation and establishment) than the second and third years. However, increasing the irrigation tended to reduce OD, AC, and EU burdens, while the $\mathrm{N}$ fertilization at the highest dose exacerbated OD and EU. Considering all impact categories, giant reed resulted as the winner crop simply because of the clearly highest productivity under the same growing conditions, input supply, and bioconversion technology. However, as emphasized by many studies, open questions still remain about benefits and burdens deriving from the use of energy crops, because positive or negative effects strongly depend on different methodological assumptions and technical means $[5,6,11,42]$. The use 
of agricultural input like irrigation and fertilization to increase biomass yield, which is the key trait in environmental studies, is unacceptable for bioenergy crops, and it might add further uncertainty to the result interpretation. As long as LCA is not able to adequately address water use, a careful site-specific analysis of water availability is necessary before recommending this agronomic practice, because irrigation of non-food crops may reduce water availability for other crops, causing water-induced iLUC. Excessive fertilization should be avoided in light of the present results because it can cause further environmental burdens. This is particularly true under these favourable climate conditions and soil type (deep loam) with good macronutrient availability and organic matter content. On the contrary, in areas with a lower fertility or other factors limiting crop growth, fertilization, also through organic fertilizers, is fundamental to maintain or improve soil fertility for the whole plant lifespan.

Other sources of uncertainty might be related to the post-harvest and technological processes. Data for the transportation, storage and bioconversion were assumed for feedstock at $15 \%$ moisture content for both crops. While miscanthus matched these values at the harvest time, giant reed biomass was usually wetter, which could add further environmental burdens associated with the downstream phases. In a sensitivity analysis, Schmidt et al. [6] found out that drying giant reed using light fuel oil instead of natural gas worsened the GHG balance significantly due to the higher $\mathrm{CO}_{2}$ emissions during combustion. The use of biomass instead of natural gas for drying largely decreased GHG emissions but at the expenses of biomass quantity to produce renewable heat and power and so less GHG savings.

Although a quantitative assessment of the uncertainty related to the use of unrepresentative data may be preferable, and despite the efforts made in the past years to decrease the uncertainty in LCA outcomes, other studies showed that even when using robust statistical methods for the uncertainty analysis, such as the Monte Carlo simulation, the uncertainty sometimes remains too high to identify a statistically significant alternative [43].

\section{Conclusions}

Main findings suggested giant reed had a greater performance than miscanthus in terms of biomass yield, aboveground $\mathrm{CO}_{2}$-sequestration, and environmental impact of biomass use for heat production. In the present environmental and soil conditions, giant reed responded positively to reduced irrigation $\left(\mathrm{I}_{25}\right)$, but the ceiling yield was achieved one year earlier when irrigation was increased $\left(\mathrm{I}_{75}\right)$. On the contrary, miscanthus needed high water volume to get most out its potential yield. The nitrogen effect was not obvious in both crops; therefore, it is recommended to reduce this input to further improve not only the non-renewable energy use and global warming potential but also the overall net environmental benefit.

In general, large environmental benefits were achieved for NREU and GWP impact categories after normalisation on average European inhabitant equivalent and following crop establishment (from second growing season onward). However, unlike the positive impacts on GHG-emissions and fossil energy consumption saved, other activities affecting the environment (i.e., land use change emission, soil carbon pools, soil nutrient content, and ecosystem services) should be accounted for when the evaluation of environmental burdens associated with bioenergy production is conducted because they may carry environmental risks in other areas.

It is worth mentioning that an uncertainty analysis was not considered in the present study, and the result interpretation derived from specific site conditions, crop management, bioconversion, system boundaries, and reference system; hence, it is highly recommended to limit these findings to the cultivation area and post-harvest technologies used to compare the bioenergy and the fossil fuel chain assumed in the present study.

Author Contributions: All authors contributed equally to this work. All authors have read and agreed to the published version of the manuscript. 
Funding: The research was partly supported by the Italian Ministry of Agriculture in the framework of the project "Sustainable innovative techniques for energy and non-food crops (TISEN)".

Institutional Review Board Statement: Not applicable.

Informed Consent Statement: Not applicable.

Data Availability Statement: Data is not applicable.

Acknowledgments: Authors gratefully acknowledge Carmelo Maugeri, Matteo Maugeri, and Dario Maugeri of the University of Catania for field trial set-up and maintenance.

Conflicts of Interest: The authors declare no conflict of interest.

\section{References}

1. DIRECTIVE (EU) 2018/2001 of the European Parliament and of the Council of 11 December 2018 on the Promotion of the Use of Energy from Renewable Sources (Recast). Official Journal of the European Union, L 328/82. Available online: https: / / eur-lex.europa.eu/eli/dir/2018/2001/oj (accessed on 15 March 2021).

2. Von Cossel, M.; Lewandowski, I.; Elbersen, B.; Staritsky, I.; Van Eupen, M.; Iqbal, Y.; Mantel, S.; Scordia, D.; Testa, G.; Cosentino, S.L.; et al. Marginal agricultural land low-input systems for biomass production. Energies 2019, 12, 3123. [CrossRef]

3. Scordia, D.; Cosentino, S.L. Perennial Energy Grasses: Resilient Crops in a Changing European Agriculture. Agriculture 2019, 9, 169. [CrossRef]

4. Lewandowski, I.; Scurlock, J.M.; Lindvall, E.; Christou, M. The development and current status of perennial rhizomatous grasses as energy crops in the US and Europe. Biomass Bioenergy 2003, 25, 335-361. [CrossRef]

5. Monti, A.; Fazio, S.; Venturi, G. Cradle-to-farm gate life cycle assessment in perennial energy crops. Eur. J. Agron. 2009, 31, 77-84. [CrossRef]

6. Schmidt, T.; Fernando, A.L.; Monti, A.; Rettenmaier, N. Life Cycle Assessment of Bioenergy and Bio-Based Products from Perennial Grasses Cultivated on Marginal Land in the Mediterranean Region. Bioenergy Res. 2015, 8, 1548-1561. [CrossRef]

7. Kim, S.; Dale, B.E. Life cycle assessment of various cropping systems utilized for producing biofuels: Bioethanol and biodiesel. Biomass Bioenergy 2005, 29, 426-439. [CrossRef]

8. Von Blottnitz, H.; Curran, M.A. A review of assessments conducted on bio-ethanol as a transportation fuel from a net energy, greenhouse gas, and environmental life cycle perspective. J. Clean. Prod. 2007, 15, 607-619. [CrossRef]

9. Pimentel, D.; Patzek, T. Ethanol production using corn, switchgrass, and wood; biodiesel production using soybean and sunflower. Nat. Resour. Res. 2005, 14, 65-76. [CrossRef]

10. Farrell, A.E.; Plevin, R.J.; Turner, B.T.; Jones, A.D.; O'Hare, M.; Kammen, D.M. Ethanol can contribute to energy and environmental goals. Science 2006, 311, 506-508. [CrossRef]

11. Cherubini, F.; Bird, N.D.; Cowie, A.; Jungmeier, G.; Schlamadinger, B.; Woess-Gallasch, S. Energy- and greenhouse gas-based LCA of biofuel and bioenergy systems: Key issues, ranges and recommendations. Resources. Conserv. Recycl. 2009, 53, 434-447. [CrossRef]

12. IPCC. Climate Change 2013: The Physical Science Basis. Contribution of Working Group I to the Fifth Assessment Report of the Intergovernmental Panel on Climate Change; Stocker, T.F., Qin, D., Plattner, G.-K., Tignor, M., Allen, S.K., Boschung, J., Nauels, A., Xia, Y., Bex, V., Midgley, P.M., Eds.; Intergovernmental Panel on Climate Change, Cambridge University Press: Cambridge, UK; Cambridge, CA, USA, 2013.

13. Loizidou, M.; Giannakopoulos, C.; Bindi, M.; Moustakas, K. Climate change impacts and adaptation options in the Mediterranean basin. Reg. Environ. Chang. 2016, 16, 1859-1861. [CrossRef]

14. Ayangbenro, A.S.; Babalola, O.O. Reclamation of arid and semi-arid soils: The role of plant growth-promoting archaea and bacteria. Curr. Plant Biol. 2021, 25, 100173. [CrossRef]

15. Von Cossel, M.; Wagner, M.; Lask, J.; Magenau, E.; Bauerle, A.; Cossel, V.V.; Warrach-Sagi, K.; Elbersen, B.; Staritsky, I.; van Eupen, M.; et al. Prospects of bioenergy cropping systems for a more social-ecologically sound bioeconomy. Agronomy 2019, 9, 605. [CrossRef]

16. Panoutsou, C.; Chiaramonti, D. Socio-Economic Opportunities from Miscanthus Cultivation in Marginal Land for Bioenergy. Energies 2020, 13, 2741. [CrossRef]

17. Cosentino, S.L.; Scordia, D.; Sanzone, E.; Testa, G.; Copani, V. Response of giant reed (Arundo donax L.) to nitrogen fertilization and soil water availability in semi-arid Mediterranean environment. Eur. J. Agron. 2014, 60, 22-32. [CrossRef]

18. Cosentino, S.L.; Riggi, E.; Testa, G.; Scordia, D.; Copani, V. Evaluation of European developed fibre hemp genotypes (Cannabis sativa L.) in semi-arid Mediterranean environment. Ind. Crops Prod. 2013, 50, 312-324. [CrossRef]

19. Scordia, D.; van den Berg, D.; van Sleen, P.; Alexopoulou, E.; Cosentino, S.L. Are herbaceous perennial grasses suitable feedstock for thermochemical conversion pathways? Ind. Crops Prod. 2016, 91, 350-357. [CrossRef]

20. Doorenbos, J.; Pruitt, W.O. Guidelines for predicting crop water requirements. In Irrigation and Drainage Paper No. 24; FAO: Rome, Italy, 1977; Volume 179. 
21. ISO 14040:2006. Environmental Management-Life cycle Assessment-Principles and Framework; International Organization for Standardization: Geneva, Switzerland, 2006.

22. ISO 14044:2006. Environmental Management-Life Cycle Assessment-Requirements and Guidelines; International Organization for Standardization: Geneva, Switzerland, 2006.

23. Institute for Energy and Environmental Research. Available online: https://www.ifeu.de/en/project/biofit-fair/ (accessed on 15 March 2021).

24. Alexopoulou, E.; Zanetti, F.; Scordia, D.; Zegada-Lizarazu, W.; Christou, M.; Testa, G.; Cosentino, S.L.; Monti, A. Long-Term Yields of Switchgrass, Giant Reed, and Miscanthus in the Mediterranean Basin. Bioenergy Res. 2015, 8, 1492-1499. [CrossRef]

25. Mantineo, M.; D’Agosta, G.M.; Copani, V.; Patanè, C.; Cosentino, S.L. Biomass yield and energy balance of three perennial crops for energy use in the semi-arid Mediterranean environment. Field Crops Res. 2009, 114, 204-213. [CrossRef]

26. Bouwman, A.F.; Boumans, L.J.M.; Batjes, N.H. Modeling global annual $\mathrm{N}_{2} \mathrm{O}$ and NO emissions from fertilized fields. Glob. Biogeochem. Cycles 2002, 16, 1080. [CrossRef]

27. Bouwman, A.F.; Boumans, L.J.M.; Batjes, N.H. Estimation of global NH3 volatilization loss from synthetic fertilizers and animal manure applied to arable lands and grasslands. Glob. Biogeochem. Cycles 2002, 16, 1024. [CrossRef]

28. IPCC (Intergovernmental Panel on Climate Change). Guidelines for National Greenhouse Gas Inventories; Egglestone, H.S., Buendia, L., Miwa, K., Ngara, T., Tanabe, K., Eds.; Volume 4: Agriculture, Forestry and Other Land Use; Prepared by the National Greenhouse Gas Inventories Program; IGES: Kanagawa, Japan, 2006.

29. Peter, C.; Fiore, A.; Hagemann, U.; Nendel, C.; Xiloyannis, C. Improving the accounting of field emissions in the carbon footprint of agricultural products: A comparison of default IPCC methods with readily available medium-effort modeling approaches. Int. J. Life Cycle Assess 2016, 21, 791-805. [CrossRef]

30. Di, H.J.; Cameron, K.C. Calculating nitrogen leaching losses and critical nitrogen application rates in dairy pasture systems using a semi-empirical model. N. Z. J. Agric. Res. 2000, 43, 139-147. [CrossRef]

31. Huijbregts, M.A.J.; Steinmann, Z.J.N.; Elshout, P.M.F.; Stam, G.; Verones, F.; Vieira, M.; Zijp, M.; Hollander, A.; Van Zelm, R. ReCiPe2016. A harmonized life cycle impact assessment method at midpoint and endpoint level. Int. J. Life Cycle Assess 2017, 22, 138-147. [CrossRef]

32. Habersatter, K.; Fecker, I.; Dall'Acqua, S.; Fawer, M.; Fallscheer, F.; Förster, R. Ökoinventare für Verpackungen Vol I + II, Swiss Agency for the Environment, Forests and Landscape (BUWAL), Schriftenreihe Umwelt Nr 250/ I+II, 2nd Corrected and Updated Version; Korrigierte und Aktualisierte Auflage: Bern, Switzerland, 1998.

33. Houghton, J.T.; Meira Filho, L.G.; Bruce, J.; Lee, H.; Callander, B.A.; Haites, E.; Harris, N.; Maskell, K. Climate change 1994. In Radiative Forcing of Climate Change and an Evaluation of the IPCC IS92 Emission Scenarios; Cambridge University Press: Cambridge, UK, 1994.

34. Houghton, J.T.; Meira Filho, L.G.; Callander, B.A.; Harris, N.; Kattenberg, A.; Maskell, K. Climate change 1995. In The Science of Climate Change; Contribution OF Wgi to the Second Assessment Report OF the Intergovernmental Panel on Climate Change; Cambridge University Press: Cambridge, UK, 1995.

35. Wenzel, H.; Hauschild, M.; Alting, L. Environmental assessment of products. In Volume 1: Methodology, Tools and Case Studies in Products Development; Chapman \& Hall: London, UK, 1997.

36. Hauschild, M.; Wenzel, H. Environmental Assessment of Products; Chapman \& Hall: London, UK, 1998.

37. Weidema, B.P. Multi-user test of the data quality matrix for product life cycle inventory data. Int. J. Life Cycle Assess. 1998, 3 , 259-265. [CrossRef]

38. Monti, A.; Zegada-Lizarazu, W. Sixteen-year biomass yield and soil carbon storage of giant reed (Arundo donax L.) grown under variable nitrogen fertilization rates. Bioenergy Res. 2016, 9, 248-256. [CrossRef]

39. Copani, V.; Cosentino, S.L.; Testa, G.; Scordia, D. Agamic propagation of giant reed (Arundo donax L.) in semi-arid Mediterranean environment. Ital. J. Agron. 2013, 8, 18-24.

40. Scordia, D.; Zanetti, F.; Varga, S.S.; Alexopoulou, E.; Cavallaro, V.; Monti, A.; Copani, V.; Cosentino, S.L. New Insights into the Propagation Methods of Switchgrass, Miscanthus and Giant Reed. Bioenergy Res. 2015, 8, 1480-1491. [CrossRef]

41. Lewandowski, I.; Clifton-Brown, J.; Trindade, L.M.; van der Linden, G.C.; Schwarz, K.U.; Müller-Sämann, K.; Anisimov, A.; Chen, C.L.; Dolstra, O.; Donnison, I.; et al. Progress on optimizing miscanthus biomass production for the European bioeconomy: Results of the EU FP7 project OPTIMISC. Front. Plant Sci. 2016, 18, 1620. [CrossRef]

42. Lewandowski, I.; Heinz, A. Delayed harvest of miscanthus-influences on biomass quantity and quality and environmental impact of energy production. Eur. J. Agron. 2003, 19, 45-63. [CrossRef]

43. Cherubini, E.; Franco, D.; Zanghelini, G.M.; Soares, S.R. Uncertainty in LCA case study due to allocation approaches and life cycle impact assessment methods. Int. J. Life Cycle Assess. 2018, 23, 2055-2070. [CrossRef] 